\title{
PENGGUNAAN MEDIA FOTO SEBAGAI ALAT KETERAMPILAN MENGKOMUNIKASIKAN SUMBER SEJARAH MELALUI MODEL KOOPERATIF TIPE PICTURE AND PICTURE DALAM PEMBELAJARAN SEJARAH
}

Oleh

\author{
Yovita Dayanti \\ (1710111220031) \\ Program Studi Pendidikan Sejarah Fakultas Keguruan dan Ilmu Pendidikan \\ Universtas Lambung Mangkurat \\ Banjarmasin
}

Email: 1710111220031@mhs.ulm.ac.id

\begin{abstract}
Abstrak :
Saat ini telah banyak dirasa kurangnya semangat nasionalisme dan juga cinta tanah air. Hal ini terjadi dikarenakan berbagai faktor yang dapat mempengaruhi secara sadar ataupun tidak sadar. Peran pendidikan disini sangat berarti sebagai ilmu pengetahuan serta pembangkit semangat nasionalisme siswa. Maka sudah selayaknya kita mulai kembali menanamkan hal tersebut. Melakukan hal ini bisa melalui berbagai bidang salah satunya belajar sejarah untuk mengetahui sumber sejarah kemudian dikomunikasikan agar dapat tersampaikan maksud atau nilai dari sumber sejarah tersebut.

Penggunaan media foto disini dimaksudkan sebagai alternatif untuk memulai pengenalan sumber sejarah kepada siswa. Hal ini tentu saja dapat dikaitan dengan model pembelajaran Picture and Picture yang mana akan mempermudah pembelajaran siswa di kelas. Pada hal ini foto digunakan untuk upaya analisa siswa terhadap seuatu kejadian, kemudian dikomunikasikanlah hasil dari analisa dengan harapan agar dapat menciptakan cara pandang baru bagi yang lain di dalam pembelajaran sejarah.
\end{abstract}

Kata kunci : model picture and picture, pembelajaran sejarah dan keterampilan komunikasi. 


\section{PENDAHULUAN}

Pada masa sekarang ini, kegiatan belajar menjadi suatu hal yang tidak dapat dipisahkan dari kehidupan manusia. Hampir di sepanjang waktunya manusia melakukan kegiatan belajar. Mengajar adalah proses membimbing sebuah kegiatan belajar. Oleh karena itu, pada hakikatnya kegiatan ini akan selalu ada terutama pada bangku pendidikan.

Sebagai proses belajar dan mengajar tentu dilakukan berbagai inovasi dan penggunaan berbagai upaya untuk menarik minat dalam penyampaian kebenaran. Mengapa hal ini sangat penting ? Karena dengan hal tersebut akan membuat proses belajar mengajar menjadi interaktif dan juga sebagai pembaharuan proses dan belajar mengajar terutama pada pembelajaran sejarah di setiap sekolah atau instansi pendidikan lainnya.

Pembelajaran sejarah merupakan pelajaran yang sudah diajarkan sejak dini dan juga dapat dilihat secara langsung melalui pembelajaran di dalam kelas maupun pada keseharian. Biasanya untuk pembelajaran sejarah ini kebanyakan selalu menggunakan model pembelajaran lama yakni ceramah yang mana dirasa terlalu membosankan bagi orang awam. Masih banyak sekolah yang kurang melakukan inovasi dalam pembelajaran sejarah, padahal pembelajaran sejarah sendiri sangat penting mengingat penanaman konsep nasionalisme di bangku sekolah salah satunya melalui mata pelajaran sejarah.

Namun tak luput dari hal ini hendaknya dilakukan berbagai hal yang menarik minat generasi muda, bisa saja digunakan berbagai strategi dalam pembelajaran sejarah. Strategi-strategi ini akan membantu dalam pembaharuan pembelajaran sejarah, agar menemukan inovasi yang mengarah kepada menarik minat peserta didik untuk menggemari pelajaran sejarah di sekolah.

Dalam dunia pendidikan, strategi pembelajaran dapat diartikan sebagai perencanaan yang berisi tentang rangkaian kegiatan yang didesain untuk mencapai tujuan pendidikan tertentu. Suryono (2016: 20), mengatakan bahwa tedapat berbagai cara dalam menerapkan teknik pembelajaran atau taktik belajar untuk bisa mencapai tujuan pembelajaran yang kita inginkan. Sehingga guru dituntut untuk melakukan inovasi-inovasi yang bersifat interaktif bagi siswa agar menciptakan suasana belajar yang menyeangkan dan disenangi siswa.

Penggunaan media tak ayal juga membantu dalam pembelajaran sejarah agar semakin efektif dalam penyampaian sumber sejarah. Heri Susanto (2014: 95) secara garis besar strategi pembelajaran dapat diartikan sebagai serangkaian tindakan perencanaan yang mencakup pengaturan cara penyampaian materi ajar, 
cara memaksimalkan kemampuan belajar peserta didik, cara menggunakan sumberdaya yang tersedia, pengaturan materi ajar dan evaluasi hasil belajar yang tersusun dalam desain pembelajaran (instruksional).

Heri Susanto dan Helmi Akmal (2019: 14) dalam bukunya menyebutkan bahwa media adalah segala sesuatu yang menjadi perantara. Maka dari itu dengan adanya media sebagai perantara bahan ajar, maka akan membuat proses belajar mengajar menjadi lebih diminati. Maka dari itu penggunaan media sebagai alternatif pembantu dalam pembelajaran sejarah untuk mengkomunikasikan sumber sejarah tersebut.

\section{MODEL KOOPERATIF TIPE PICTURE AND PICTURE}

Proses belajar mengajar dapat berjalan efektif apabila seluruh komponen berpengaruh saling mendukung dalam rangka mencapai tujuan pembelajaran. Menurut Johnson \& Johnson (dalam Djamarah, 2006: 55) model pembelajaran picture and picture adalah pembelajaran mengandalkan gambar sebagai dalam media proses pembelajaran. Sehingga sebelum proses pembelajaran guru sudah menyiapkan gambar yang akan ditampilkan baik dalam bentuk kartu atau dalam bentuk cerita dalam ukuran besar. Diharapkan dengan hal ini dapat mempermudah pemahaman dari setiap siswa karena bersifat visual.

Taniredja, dkk. (2013: 55) pembelajaran kooperatif picture and picture sendiri merupakan sistem pengajaran yang memberi kesempatan pada anak didik untuk bekerja sama dengan sesama siswa dalam tugas-tugas yang berstruktur, berkelompok, sehingga terjadinya interaksi secara terbuka dan hubungan yang bersifat interdependensi efektif di antara anggota kelompok.

Sesuai dengan namanya, tipe ini menggunakan media gambar dalam proses pembelajaran yaitu dengan cara memasang/mengurutkan gambar-gambar menjadi urutan logis. Melalui cara seperti ini diharapka siswa mampu berfikir dengan logis sehingga pembelajaran menjadi bermakna.

Menurut Rahmah (2006: 38) langkah-langkah dalam model pembelajaran kooperatif tipe picture and picture adalah sebagai berikut : 1) Guru mempersiapkan gambar-gambar sesuai dengan tujuan pembelajaran. 2) Guru membagikan gambar pada setiap kelompok yang terdiri dari 4-5 orang. 3) Guru menyuruh kelompok mengidentifikasi ciri-ciri kegiatan yang ada pada gambar. 4) Melalui diskusi kelompok didapatkan kesimpulan tentang ciri-ciri gambar yang diamati. 5) Tiap kelompok diberi kesempatan untuk membacakan hasil diskusi. 6) 
Guru menjelaskan materi sesuai denga tujuan yang ingin dicapai. 7) Mencari kesimpulan.

Pengaplikasian model kooperatif tipe picture and picture ini dimaksudkan dengan upaya mencari cara pandang baru terhadap pemahaman pembelajaran sejarah yang mana dengan tujuan agar mempermudah siswa dalam menarik informasi sumber sejarah dan kemudian dikomunikasikan. Mengomunikasikannya disini dengan harapan dapat menyampaikan informasi kembali mengenai hal yang telah didapat sebelumnya.

Pengguanaan model kooperatif tipe picture and picture bukan sekedar upaya untuk membantu guru dalam megajarkan, tetapi lebih dari itu sebagai usaha memudahkan siswa dalam mempelajari materi pelajari. Diarapkan model pembelajaran ini tidak hanya dilakukan sebagai selingan mengganti kebosanan model ceramah namun diharapkan akan timbul bahwa model kooperatif tipe picture and picture telah menjadi bagian dalam sistem pendidikan sehingga dapat dimanfaatkan guru semaksimal mungkin untuk membantu kelancaran bidang tugas yang diemban untuk kemajuan dan meningkatkan kualitas peserta didik.

\section{PEMBELAJARAN SEJARAH}

Pembelajaran pada hakikatnya adalah suatu proses, yaitu proses mengatur juga merupakan proses mengorganisasi lingkungan yang ada di sekitar peserta didik sehingga dapat menumbuhkan dan mendorong peserta didik melakukan proses belajar. Pembelajaran juga dikatakan sebagai proses memberikan bimbingan atau bantuan kepada peserta didik dalam melakukan proses belajar. Kegiatan pembelajaran dimaksudkan dengan pemberian pengetahuan kepada siswa yang dilakukan oleh guru.

Di dalam Undang-Undang Republik Indonesia Nomor 20 tahun 2003 yang memaparkan tentang Sistem Pendidikan Nasional, yang mana pembelajaran adalah suatu tahapan dimana terjadinya interaksi antara guru dengan peserta didik dan sumber belajar didalam proses belajar. Untuk melakukan sebuah proses interaksi belajar, guru harus mampu mengembangkan materi yang akan disampaikan serta melakukan kegiatan inovatif agar proses pembelajaran menjadi menarik dan tidak membosankan.

Dalam hal ini sebuah pembelajaran juga didukung dengan adanya kurikulum. Sekarang ini kurikulum yang digunakan di Indonesia adalah Kurikulum 2013, yang mana pada hal ini tidak hanya menyoroti kognitifitas namun juga beriringan dengan aspek afektik dan psikomotoriknya. Pada 
kurikulum 2013 ini aspek kognitif menjadi faktor kedua di dalam penilaian kemampuan siswa. Ini dinyatakan sebagai sebuah pembaharuan di dalam dunia pendidikan selama 10 tahun terakhir ini dikarenakan aspek penilaian pertama adalah bidak afektif, yakni penilaian mengenai perilaku dan budi pekerti siswa.

Kurikulum 2013 ini menitik beratkan peserta didik sebagai poin utama dan dituntut lebih aktif mengingat guru hanya sebagai fasilitator. Dalam hal ini guru hanya memberikan arahan agar pembelajaran di kelas tidak membuat bosan, hal ini ditujukan agar pola pikir peserta didik terarah dan berhasil menyelesaikan sebuah permasalah. Berbicara mengenai aspek yang disoroti, pemerintah mengharapkan peserta didik memiliki perilaku yang baik terhadap yang lebih tua maupun pada sesama, kemudian pengetahuan yang dimiliki juga bidang yang mereka gemari. Ketiga hal tersebut akan mendapat arahan dari guru, mengingat setiap peserta didik memiliki potensi yang berbeda-beda baik dalam akademik maupun non-akademik.

Sejarah merupakan ilmu yang mempelajari suatu kejadian atau peristiwa penting dimasa lampau. Dilihat dari bahasa Arab, sejarah berasal dari kata sajaratun yang berarti adalah pohon. Ini dimaksudkan bahwa, sejarah adalah suatu kejadian yang saling memiliki keterkaitan satu sama lain serta dengan alur yang sistematis. Sedangkan menurut bahasa Yunani, sejarah berasal dari kata historia yang memiliki makna sebagai ilmu pengetahuan yang bersumber pada penelitian yang medalam agar mendapatkan suatu pembenaran.

Heri Susanto (2014: 96) materi sejarah tidak hanya dipahami sebagai sekumpulan fakta akan tetapi bagaimana peserta didik dapat memahami nilai-nilai yang terkandung di dalamnya dan mengaplikasikannya dalam kehidupan seharihari yang mana menyangkut peristiwa, tokoh, ruang dan waktu.

Menurut Heri Susanto (2014: 59) pembelajaran sejarah memiliki bebarapa karakteristik, yaitu (1) pembelajaran sejarah mengajarkan tentang kesinambungan dan perubahan, (2) jiwa zaman, (3) bersifat kronologis, (4) mengajarkan tentang perilaku manusia dan (5) pemahaman akan hukum-hukum sejarah.

Pada hal ini mempelajari pembelajaran adalah sebuah upaya untuk menumbuhkan jiwa nasionalisme, juga sebagai proses pembudayaan secara terusmenerus serta sistematis yang akan akan membentuk karakter dari peserta didik yang cinta terhadap tanah air dan juga diharapkan berjiwa patriotisme. Dengan mempelajari sejarah kita diajarkan berbagai rasa menghargai bagaimana perjuangan para pejuang untuk memperjuangkan bangsa Indonesia agar merdeka terutama di daerah kita sendiri. 


\section{KETERAMPILAN KOMUNIKASI}

Istilah komunikasi atau dalam bahasa Inggris communication berasal dari kata Latin communicatio, dan bersumber dari kata communis yang berarti sama. Sama di sini maksudnya adalah sama makna. Hal yang senada diungkapkan oleh Hafied Cangara, komunikasi berpangkal pada perkataan Latin communis yang artinya membuat kebersamaan atau membangun kebersamaan antara dua orang atau lebih.

Menurut Hafied Cangara, (Cet. XII 2011: 18-19). Sebuah definisi yang dibuat oleh kelompok sarjana komunikasi yang mengkhususkan diri pada studi komunikasi antar manusia (human communication) bahwa: komunikasi adalah suatu transaksi, proses simbolik yang menghendaki orang-orang mengatur lingkungannya dengan (1) membangun hubungan antarsesama manusia; (2) melalui pertukaran informasi; (3) untuk menguatkan sikap dan tingkah laku orang lain; serta (4) berusaha mengubah sikap dan tingkah laku itu.

Mengkomunikasikan sumber sejarah artinya menyampaikan pesan atau informasi dari sumber sejarah yang ada. Dari keterampilan mengkomunikasikan juga, orang akan mengatahui apa yang pernah terjadi di masa lampau mengenai bukti-bukti sejarah. Dalam hal ini siswa di minta mampu untuk mengambil nilai dari proses penyampaian informasi melalui sumber sejarah, agar bukti-bukti sejarah serta hal yang perlu diteladani dari masa lampau bisa menjadi pembelajaran untuk masa sekarang dan juga masa depan.

Tak hanya itu, keterampilan dalam mengkomunikasikan sumber sejarah dijadikan sebagai sebuah cara pandang baru dalam membuka wawasan terhadap fakta yang telah ada. Mengenai fakta dari sejarah lokal saja bisa berbeda cara pandang antar satu dan lain hal, maka ini pula lah yang akan menjadikan keterampilan mengkomunikasikan sumber sejarah dengan bervariatif.

Pemahaman terhadap sejarah lokal disini juga menjadi salah satu aspek yang sangat menyenangkan untuk siswa didalam sebuah keterampilan berkomunikasi, dimana dengan melakukan pembahasan tentang hal tersebut akan menciptakan rasa keingin tahuaan dari siswa tersebut, terutama sejarah daerahnya dimasa lampau. Dibalik dari keterampilan mengkomunikasikan sumber sejarah ini juga upaya untuk melatih kemampuan public speaking dari siswa tersebut. Dimana public speaking sendiri sangat bermanfaat untuk siswa tersebut, terutama untuk masa depannya sendiri salah satunya di dunia pekerjaan nantinya. 


\section{PENUTUP}

Penggunaan model kooperatif tipe picture and picture ini dimaksudkan menjadi salah satu alternatif dalam inovasi pembelajaran sejarah agar menciptakan kesan yag menyenangkan. Dengan adanya foto sebagai media menjadikan model ini semangat atraktif bagi siswa yang dibagi perkoelompok dan melatih kekompakan antar siswa di dalam kelompoknya. Sehingga membuat suasana kelas menjadi menyenangkan dan tentunya tidak membuat siswa menjadi bosan sesuai dengan tugas guru sebagai fasilitator yang ada di ketentuan kurikulum 2013.

Keterampilan komunikasi dalam hal ini akan menghasilkan sebuah cara pandang baru terhadap sebuah sumber sejarah, yang mana akan menjadikan sebuah dialog baru dari keterampilan tersebut. Hal ini juga yang diharapkan dari penerapan model koopertif ini. Membangun sebuah kemampuan public speaking yang bagus akan menjadi sebuah benefit dari penerapan keterampilan berkomunikasi ini. Dalam hal ini juga berkaitan erat dengan penyampaian faktafakta sejarah yang akan membangun rasa memiliki terhadap daerahnya, cinta tanah air dan berjiwa patriotisme.

\section{DAFTAR PUSTAKA}

Suryono \& Hariyanto. 2016. Belajar dan Pembelajaran: Teori dan Konsep Dasar. Bandung : Remaja Rosdakarya. Hal: 20.

Susanto, Heri. 2014. Seputar Pembelajaran Sejarah: Isu, Gagasan dan Strategi Pembelajaran. Banjarmasin : Aswaja Pressindo. Hal: 95, 96, 59.

Susanto, Heri \& Helmi Akmal. 2019. Media Pembelajaran Sejarah Era Teknologi Informasi (Konsep Dasar, Prinsip Aplikatif dan Perancangannya). Banjarmasin: Program Studi Pendidikan Sejarah FKIP Universitas Lambung Mangkurat. Hal: 14.

Djamarah, Syaiful Bahri. 2006. Strategi Belajar Mengajar. Jakarta: Rineka Cipta. Hal: 55.

Taniredja, Tukiran, Efi Miftah Faridli \& Sri Harmianto. 2011. Model-Model Pembelajaran Inovatif. Bandung: Alfabeta. Hal: 55 
Johar, Rahmah dkk. 2006. Strategi Belajar Mengajar. Banda Aceh: Universitas Syiah Kuala. Hal: 38.

Depdiknas, Undang-undang Republik Indonesia Nomor 20 Tahun 2003 tentang Sistem Pendidikan Nasional, BP Panca Usaha, Jakarta, 2005.

Prawitasari, Melisa. 2018. Sejarah Gerakan Kepemudaan di Kalimantan Selatan. Banjarmasin: Dinas Pemuda dan Olahraga.

Cangara, Hafied. Pengantar Ilmu Komunikasi, Cet. XII, (Jakarta: PT.Rajagrafindo, 2011). Hal: 18-19.

PRAWITASARI, Melisa. Metode Pembelajaran Hypnoteaching Melalui Mind Mapping Dalam Pembelajaran Sejarah (Studi Pada Siswa Kelas XI IPS SMA PGRI 6 Banjarmasin). Jurnal Pendidikan Sejarah untuk Menyiapkan Generasi Emas Indonesia 2050.

SUSANTO, Heri. Pemahaman Sejarah Daerah dan Presepsi Terhadap Keberagaman Budaya Dalam Membina Sikap Nasionalisme. 2017. Jurnal Sejarah dan budaya. Tahun Kesembilan. No.1

Prawitasari, Melisa. 2017. Workshop Pembelajaran Sejarah Berbasis Paperless Clash Melalui Kegiatan Mahasiswa Praktik Mengajar di Sekolah. Banjarmasin. Pengabdian. 